\title{
Productive Comparative Angst: Comparative Literature in the Age of Multiculturalism
}

\section{By LINDA HUTCHEON}

The current explosion of interest in the state of the discipline called comparative literature may be a sign of institutional anxiety or intellectual excitement - or perhaps both. The rapid publication of the book Comparative Literature in the Age of Multiculturalism, edited by Charles Bernheimer,' is more than a tribute to the efficiency and publishing savvy of the Johns Hopkins University Press; it is a sign of the urgency felt by comparativists to rethink and even to reconfigure their affiliations in the light of recent intellectual and academic realignments. Within a year of the December 1993 Modern Language Association convention, at which the newest public debate formally began, this collection of essays has made available for even wider discussion the American Comparative Literature Association's 1993 Bernheimer Report entitled "Comparative Literature at the Turn of the Century." Following on books like The Comparative Perspective on Literature: Approaches to Theory and Practice.' this volume joins a host of others? in examining what it calls the "anxiogenic" state of comparative literature in the United States (and elsewhere) today.

This state of anxiety may well feel familiar to those who recall René Wellek's 1958 worries (in "The Crisis of Comparative Literature")" about the lack of both subject matter and methodology in what many refer to by the contraction "CompLit." Indeed, as Bernheimer notes in his introduction, the various shifts in the discipline's focus "since World War II can be viewed as a series of attempts to cure, contain, or exploit the anxiety of comparison" (3). The most recent in this series of attempts was brought about by that new ACLA document: just like the Levin Report of 1965 and the Greene Report of 1975, the 1993 Bernheimer Report is unavoidably the product of a particular generation of comparativists.' The reprinting in this volume of these three reports makes possible the kind of comparison that clearly reveals the generational shift

LINDA HUTCHEON is Professor of English and Comparative Literature at the University of Toronto. She is the auth or of eight books, the latest of which is Irony 's Edge: The Theory and Politics of Irony (1995). from the Americanization of the work of those postwar European émigré philologists and literary historians, through to the domestication of what was called "theory" when it was housed in comparative literature departments, to the current questioning of the centrality of the "Lit" in CompLit. Tellingly, perhaps, the first two were called reports "on standards"; the most recent one has been amended by the ACLA to bear the title of a report on "the state of the discipline."

The second section of Comparative Literature in the Age of Multiculturalism contains the three responses to the Bernheimer Report-by K. Anthony Appiah, Mary Louise Pratt, and Michael Riffaterre - that were presented for debate at the 1993 MLA convention. The third and largest section is given over to thirteen "position papers" from respected comparativists of several generations, responding in turn not only to the reports themselves but also to the very different stances taken in the three MLA papers. Chosen for the "diversity in critical perspective and institutional affiliation" (xi) they represented, these scholars offer a wide range of opinion and position. In short, if you come to Comparative Literature in the Age of Multiculturalism looking for a single answer to any of your worries about the discipline, or if you are not comfortable with the postmodern-ly plural and contingent, you will not find your anxieties lessened by your reading. This is not a book for the faint of (metanarrative) heart.

It is, however, a book for provoking thought, specifically thought on four major areas of concern for comparativists today, as reflected in the Bernheimer Report: 1) the historical Eurocentrism of the CompLit tradition and its relation to the multicultural reality of the present; 2) the continuing concerns about the desirability of reading-and comparing-literatures in their original languages and not in translation; 3) the position of theory in the discipline today; 4) the debate between what might be called the "formalists" and the "contextualists"or, in institutional terms, literary studies versus cultural studies.

Few would deny that the history of comparative literature in North America is the history of its European émigré founding fathers; for some, that past 
has lived on as a kind of cosmopolitan, "poetic Euro-chic'" that may still be worn as a " 'classy' designer label" tod ay.' While even the 1965 Levin Report stressed the need to transcend that cultural limitation and the 1975 Greene Report emphasized the "global" nature of literature, the discipline has nonetheless largely remained based in European literary and historical traditions. The essays in this volume thoughtfully combat any knee-jerk rejection of this fact, however. K. Anthony Appiah urges: "Study these interconnected European literatures, I say. They make sense together. They were made for each other.:" However, he goes on, study as well other interconnected bodies of writing that cohere around other cultural notions in other parts of the world. David Damrosch also reminds us that, in the face of the enormous scope of comparative literature's "mission," working within only the European languages may have been, for European-trained scholars, "less a matter of cultural imperialism than it was a melancholy acceptance of unbridgeable limits. "9

The early constructions of the field - like those of other fields of literary study - have now been called into question because of their omissions, omissions made more evident through the increasingly diverse demographics not only of North American society but of the North American academy itself. As an internationalist discipline, comparative literature could not remain untouched by the pluralistic demands for canon revision and the ethical considerations vis-à-vis minoritized groups that were part of the contested academic and intellectual climate of the 1980s. In fact, it has faced particular and particularly troublesome problems because of its comparative function. These included problems as different as accusations of implied universalism, on the one hand, and, on the other, charges of essentializing in the face of the mimetic imperative that often accompanies notions of authenticity. There have been problems caused by geopolitical complexities and the historical processes of globalization, democratization, and decolonization that are collectively changing how literature and culture have been understood and studied. ro And, of course, there have been problems caused by the image of the comparativist as colonizing imperialist taking over individual linguistic and literary domains.

The Bernheimer Report's advocacy of "a pluralized and expanded contextualizing of literary studies" (11) is one response to these diverse problems, one to which I will return shortly. But a number of the contributors to this volume suggest that com- parative literature, by its very nature, is already a particularly "hospitable space" for what Mary Louise Pratt calls "the cultivation of multilingualism, polyglossia, the arts of cultural mediation, deep intercultural understanding, and a genuinely global consciousness" (62). This utopian view of CompLit as the "site for powerful intellectual renewal in the study of literature and culture" (62) is part of its history too, in a way: in the nervous postwar years of its North American founding, it was seen as representing "the spirit of peace, sincerity, reas on ableness, and hope." "Inherently pluralist, CompLit is argued to be "aware of but not defined by Difference in all its powerful forms: language, religion, race, class, and gender." ${ }_{12}$ This idea of the discipline as "a theoretical free space and a more cosmopolitan environment for multilingual and multiaccentual community" 13 goes a long way toward making comparative literature into the "humanities counterpart to international relations.'?"

The dissenting view in the volume is that of those like Emily Apter who suggest that CompLit's day may in fact have passed, that now is the time for postcolonial and not comparative studies: "With its interrogation of cultural subjectivity and attention to the tenuous bonds between identity and national language, postcolonialisrn quite naturally inherits the mantle of comparative literature's historical legacy.'"; While Apter and others reject that implied consensual or utopian model in favor of a dissen sual one that would confront First with Third World cultures, Rey Chow offers an important reminder: "Instead of being a blank space ready to be adopted or as similated by comparative literature, non-Western language and literature programs have been sites of production of knowledge which function alongside United States State Department policies vis-avis the particular nations and cultures concerned" (108). From another angle, David Damrosch stresses the need to historicize and contextualize imperialism. Empire is not a recent phenomenon; it is not only a European one (126).

Postcolonial work is, of course, being done in national literature departments as well, largely because of its frequently unilingual focus: the cultural power of colonialism lives on in language. This brings me to the second source of anxiety for comparativists-ethe familiar one of linguistic competence and of the pedagogic and ethical issues involved in "engaging" two or more literatures adequately in their original languages. The question of the use of translations has provoked a predictable "elitist versus populist" debate." However, multilingualism, as we are re- 
minded in this volume, is in itself trans-ideological in the sense that it can "as easily serve the agenda of reactionary politics as it can serve progressive ones." " Thus, its intrinsic positive value (assumed in the Levin and Greene Reports) is called into question, even as the limits of unilingualism are recognized: not all literary concerns can be satisfactorily investigated through translations. Elizabeth FoxGenovese takes a strong stand on this issue, urging the seeking of alternatives to the use of translations with its implicit throwing up of hands because "we are too limited (read imperialist) to appreciate it in the original" (135). A sensible and attractive alternative is the one offered by Damrosch: collaborative work for scholars and collaborative training for students (132).

The issue of translation merges with that of Eurocentric critique in the third area of common concern among the contributors to Comparative Literature in the Age of Multiculturalism. The ready availability of English versions of the European structuralist and poststructuralist theorists' work has threatened CompLit departments' housing of theory: national literature departments of all kinds can now "do" theory. There is little doubt that the rise and fall of the institutional power and cohesion of the Yale Comparative Literature group has left its mark on the discipline and, many would argue, upon the very process of reading. The comparativists who write for this volume, however, are divided in their views of the continuing importance of theory to CompLit's self-definition. Yale's current chair of Comparative Literature, Peter Brooks, feels theory is still the lingua franca of the discipline (103), and Elizabeth Fox-Genovese feels it would "be difficult to imagine comparative literature without theory, not least since the mere posing of the comparative problem is inherently theoretical" (139). Appiah, on the other hand, while agreeing that theory has been important historically to CompLit, does not see it as either the goal or the defining uniqueness of the discipline (53).

The theories of textuality that the Yale School represented are not, of course, the only components of what we lump together these days as "theory," and that comes through loud and clear in the position papers published in this book. With the increasing importance of feminist theory in North America, a major interest in context-social, cultural, historical, political context-was added to the concern with textuality. The impact of feminist work dovetailed with the theories of Foucault, Bakhtin, and Benjamin, and of Marxist, postcolonial, New His- torical, gay and lesbian (and queer) theorists to make ideology an unavoidable issue in literary studies, comparative or otherwise. One of the results of this shift of focus has been the rise of a North American version of what in Britain had been dubbed cultural studies. The Bernheimer Report expresses this shift in quite cautious terms as a broadening of the field of inquiry that "does not mean that comparative study should abandon the close analysis of rhetorical, prosodic, and other formal features but that textually precise readings should take account as well of the ideological, cultural, and institutional contexts in which their meanings are produced" (43) .

This may sound like a safe-enough compromise, but the strong reactions of contributors would suggest otherwise. While accepting that formal and contextual studies are necessarily complementary, Michael Riffaterre asserts the need to "decontextualize" and focus on the esthetic features of literature." Peter Brooks protests the "abjectly apologic tone" of the Report which suggests that the teaching of literature is "an outmoded mandarin practice" (99) instead of the study of the "processes by which meaning is made, the grounds for interpretation" (101). Warning of the dangers of interdisciplinary amateurism, Brooks eloquently argues that "real" interdisciplinarity "comes when thought processes reach the point where the disciplinary boundary one comes up against no longer makes sense-when the internal logic of thinking impels a transgression of borderlines. And to the extent that this is teachable at all, it requires considerable apprenticeship in the discipline that is to be transcended" (102).

Many contributors attest to their belief in what one calls the "valuable specificity" of literature." For some, this is a reason for remaining, in Brooks's terms, a "viable Interlocutor to cultural studies," one that can insist that "contextualizations of literature in ideological and cultural terms remain aware of literature's institutional definitions and of the uses of poetics and rhetoric in understanding the ways in which literature creates meanings that both resemble and differ from those produced in other discourses" (103). But need CompLit's position here merely be one of interlocutor? Has any comparativist, even the most formalist, ever really read literature outside of some context, as not inextricably embedded in a vast set of cultural practices? This is not a rhetorical question; nor is it an utterly naive one, despite appearances. It points to my genuine puzzlement over what feels like a false dichotomy. 
The disciplinary training of a comparativist, like that of any scholar who studies English or French or Korean or Nigerian literature, teaches us all that interpretation does not happen in a vacuum, that it is always relational and dynamic. Our literary disciplines may well traffic, not in political wisdom, but in "metrics, narrative structure, double, triple and quadruple meanings," as Stanley Fish has argued;" but the analysis of, say, narrative structure just might have to deal with the fact that stories are written-and read-in certain ways for certain reasons (conscious or unconscious reasons) in certain contexts at certain times. These are the insights that our formal training allows us to carry forward to the interpretation of other cultural artifacts or other discourses. We never stop being comparative literature trainees; our "déformation professionnelle" is permanent. At least it is if we have had that training.

The ACLA document is not only a report on the state of research in the discipline as it now stands; it is a provocative challenge to broaden the scope of what we teach in CompLit departments. Like many of us, the Report's authors were formed and "deformed" as comparativists; they have that to build upon and to deploy in new areas. The inevitable danger for our students in broadening what is already an impossibly broad discipline is the loss of any useful and distinctive training, even in skills of interpretation. The result, laments Appiah, may not be interdisciplinarity but "an unstructured postmodern hodge-podge" (57). This is a warning we as teachers must heed-for our students' sakes. But I still do not think the institutional or pedagogic answer is to leave cultural studies to the national language and literature departments-where cultural specificity may indeed make such a focus logical. This is Jonathan Culler's solution, one that would leave comparativists to study "literature comparatively" and attempt "to attend to its global manifesrations.'?' But the question of cultural specificity will not go away so easily-either as a problem or as a temptation-for those engaging more than one literary or cultural tradition." Culture is no more or less "translatable" than literature. Culture, like literature, is a matter of form as much as of content."

The Bernheimer Report had advised caution for comparative literature vis-à-vis cultural studies, "where most scholarship has tended to be monolingual and focused on issues in specific contemporary popular cultures" (45). But the historical commitment of comparative studies, conjoined with the archival work of historians themselves, might be precisely what the emerging field of cultural studies could most profit from. And the seeming expansion of the scope of the discipline to include not only high art but also popular culture is maybe more apparent than real: minimal historicizing is needed to remind us that Shakespeare's plays were not what we would now call high art for the entire audience of the Globe Theater, and that writers like Rabelais deliberately chose to write in the vernacular, not in Latin." The monolingual and often parochial nature of much cultural-studies work in the recent past need not stand as the final definition of this emerging field. The addition of the work of comparativists could serve to expand it in significant ways .

Comparative literature's major disciplinary strength and major intellectual attraction have always seemed to me to lie in a positive version of what Emily Apter considers its "unhomely" quality (90) and what Bernheimer calls its "quality of dispossession-a kind of haunting by otherness" (12). I remain as worried as ever, both in pragmatic and in political terms, about its vast scope-even vaster in this new definition "charged with the study of discourses and cultural productions of all sorts throughout the entire world,":" I also share many of the contributors' worries about the possible institutional consequences of a move outward from the literary: in these days of financial constraints, unstable disciplinary boundaries can mean unstable funding." Of course, the inherent versatility of comparativists can also mean the kind of institutional flexibility that could spell survival."

If you have ever taught or been taught in a CompLit program, you will know that comparatists may appear to have little in common with one another: "As a discipline with no common body of knowledge other than literary studies, and without a central purpose except to carry out its astringent or stimulant motions, comparative literature appears to invite misunderstanding even from its own family of scholars." 28 But what Comparative Literature in the Age of Multiculturalism reveals is that any such misunderstanding is part of the intellectual vitality of the field and part of the continual self-criticism of a protean discipline that has never been willing (or able) to fix its self-definition. That is what is frustrating about CompLit, but it is also what attracted many of us to it. The ACLA, as an important professional voice for comparativist studies, has provoked productive and continuing debate on the future of the discipline through the Bernheimer Report. This is not the last word, of course. There can, luckily, be no last word on this subject.

University of Toronto 
${ }_{1}$ Comparative Literature in the Age of Multiculturalism, ed. Charles Bernheimer, Baltimore, Johns Hopkins University Press, 1995. Most page references to this volume will appear in parentheses in the text. Subsequent references in the notes will use the abbreviation $C L$.

${ }^{2}$ The Comparatiue Perspective on Literature: Approaches to Theory and Practice, eds. Clayton Koelb and Susan Noakes, Ithaca, N.Y., Cornell Univ ersity Press, 1988.

${ }_{3}$ See Bordenoorh: Feminist Engagements wich Comparative Literatu re, ed. Margaret R. Hig onnet, Ith aca, N.Y., Cornell Uni versity Press, 1994; Building a Profession: Autobiographical Perspectives on the Beginnings of Comparatiue Literature in the United States, eds. Lionel Gossman and Mihai I. Spariosu, Albany, N.Y., State University of New York Press, 1994; and the recent translation by Cola Franzen of Claudio Guill en's book The Challenge of Comparauue Literature, Cambridge, Ma., Harvard University Press, 1993.

${ }_{4}$ René Wellek, "The Crisis of Comparative Literature," in Concepts of Criticism, ed. Steph en Nichols, New Haven, Ct., Yale Un iversity Press, 1963.

${ }^{3}$ For a detailed consideration of the se generational changes, see Roland Greene, "Their Generation," in CL, pp. 143-54.

'Peter Brooks, "Must We Apologize?" in $C L$, p. 97. Further references will be in parentheses in the text.

7 Rey Chow, "In the Name of Comparative Literature," in $C L$, p. 107. Further page references will appear in parentheses in the text.

${ }^{8}$ K. Anthony Appiah, "Geist Stories," in $C L$, p. 54.

9 David Damrosch, "Literary Study in an Elliptical Age," in $C L$, p. 130 . Further page references will appear in parentheses in the text.

${ }_{10}$ Mary Loui se Pratt, "Co mparative Liter ature and Global Citizenship," in $C L$, p. 59. Further page references will appear in parentheses in the text.

${ }_{11}$ Tobin Siebers, "Sincerely Yours," in $C L$, p. 195. Siebers questions whether such a worthy social aim, however, is an adequate or even appropriate found ation for a discipline.

12 Ed Ahearn and Arnold Weinstein, "The Function of Criticism at the Present Time: The Promise of Comparative Literature," in $C L$, p. 78. They go on to note: "There is no period or place of artistic production which is not similarly mixed, crosscultural, cross-poll inated. Virgin literarures, like the virgin land, are a myth. Comparativists are the people trained to bring us this news" (79).

13 Mary Russo, "Telling Tales Out of School: Comparative Literature and Disciplinary Recession," in $C L$, p. 189.

${ }^{14}$ Ahearn and Wein stein, p. 81.

${ }_{15}$ Emily Apter, "Comparative Exile: Competing Margins in the History of Comparative Literature," in $C L$, p. 86. Further page references will appear in parentheses in the text.

${ }^{16}$ See Elizabeth Fox-Genovese, "Between Elitism and Populism: Whither Co mparative Lit erature?" in $C L$, p. 134. Further page references will be in parentheses in the text.

${ }_{17}$ Ch ow, p. 110.

${ }_{18}$ Michael Riffaterre, "On the Complementarity of Comparative Literature and Cultural Studies," in $C L$, pp . 67, 70.

${ }_{19}$ Francoise Lionnet, "Spaces of Comparison," in $C L$, p. 172. Further page references will appear in parentheses in the text.

20 Stanle y Fish, "Why Literary Criticism Is Like Virtue," London Review of Books, I0 June 1993, p. 12.

${ }_{21}$ Jonathan Cull er, "Comparative Literature, at Last!" in $C L$, p. 121.

${ }_{22}$ See the important points made by Marjorie Perloff, "'Literature' in the Expanded Field," in $C L$, p. 180; Damrosch, p. 123.

${ }^{27}$ See Siebers, pp. 196-97.

${ }_{24}$ Lionnet, p. 172

${ }^{25}$ Culler, p. 117.

${ }_{26}$ See Perloff, p. 182.

${ }_{27}$ Russo, p. 193.

${ }^{28}$ Greene, p. 145. 